\title{
Pearls \& Oy-sters: Cerebral Microbleeds Caused by Adrenocortical Adenoma-Related Primary Aldosteronism
}

Sun Min Lee, MD, PhD, Yong Jun Choi, MD, PhD, Kihwang Lee, MD, PhD, Hyeung Kyoo Kim, MD, Jin-Sun Park, MD, PhD, Yong Cheol Lim, MD, Jang-Hee Kim, MD, and So Young Moon, MD, PhD

Neurology ${ }^{\circledR} 2021 ; 96: 960-962$. doi:10.1212/WNL.0000000000011934

\section{Pearls}

- Multiple cerebral microbleeds (CMBs) increase in prevalence with age.

- Hypertension itself is not an independent factor for frequency of CMBs and workup should be performed in patients with age-advanced CMBs.

- Concomitant lobar and deep CMBs are caused by hypertensive small vessel disease rather than cerebral amyloid angiopathy (CAA).

- Primary aldosteronism (PA) can cause numerous concomitant lobar and deep CMBs in a relatively young population through oxidative stress caused by excessive aldosterone and direct injuries resulting from hypertension.

\section{Oy-sters}

- Secondary hypertension should be considered in hypertensive patients with numerous concomitant lobar and deep $\mathrm{CMBs}$ and unexplained retinal hemorrhage.

- PA could be among the differential diagnoses in hypertensive patients with concomitant lobar and deep CMBs with accompanying low serum potassium levels.

A 47-year-old man came to the outpatient neurology clinic at a university-affiliated hospital. $\mathrm{He}$ complained of word-finding difficulty and slurred speech, which had occurred abruptly with accompanying dizziness in the morning 17 days prior to the visit and had been improving since then. He was still working as a computer programmer. His past medical history was significant for hypertension (on 3 antihypertensive medications) over 7 years, a prior episode of transient vertigo with negative workup, and incidental retinal hemorrhages of unclear etiology. At his visit, his blood pressure (BP) was $145 \mathrm{~mm} \mathrm{Hg} / 95 \mathrm{~mm} \mathrm{Hg}$. On the NIH Stroke Scale (NIHSS), he was scored 1 due to mild transcortical motor aphasia. His brain MRI was taken on the same day as the appointment and revealed an acute $1.7-\mathrm{cm}$ intracranial hemorrhage (ICH) in the left superior frontal lobe with ICH score of 0 (figure, A). The MRI showed $>200 \mathrm{CMBs}$ in the junctions of the white and gray matter, basal ganglia, pons, and cerebellum on gradient echo T2weighted imaging (figure, B). In addition, 3 lacunes and white matter hyperintensities (Fazekas grade 2) were detected on T2-weighted imaging. He was instructed to keep taking his antihypertensive medications.

On the following day, the patient visited the emergency department with sudden-onset right hemiparesis, which had occurred at midnight, 1 hour prior to his visit to the emergency department. His BP was 170/115 mm Hg. He was alert and attentive but showed right arm and leg weakness in addition to mild transcortical motor aphasia (3 on NIHSS). His brain CT scan showed a new acute ICH (0 on the ICH score) in the left basal ganglia (figure, $\mathrm{C}$ ). He was admitted to the ward for conservative management of ICHs.

\author{
Correspondence \\ Dr. Moon \\ symoon.bv@gmail.com
}


Figure Brain MRI, Brain CT, ${ }^{18}$ F-Flutemetamol Amyloid PET Scan, Retinal Image, Adrenal CT, Adrenal Mass Specimen, and Histopathologic Section of Adrenocortical Adenoma in a Patient With Adrenocortical Adenoma Associated With Primary Aldosteronism

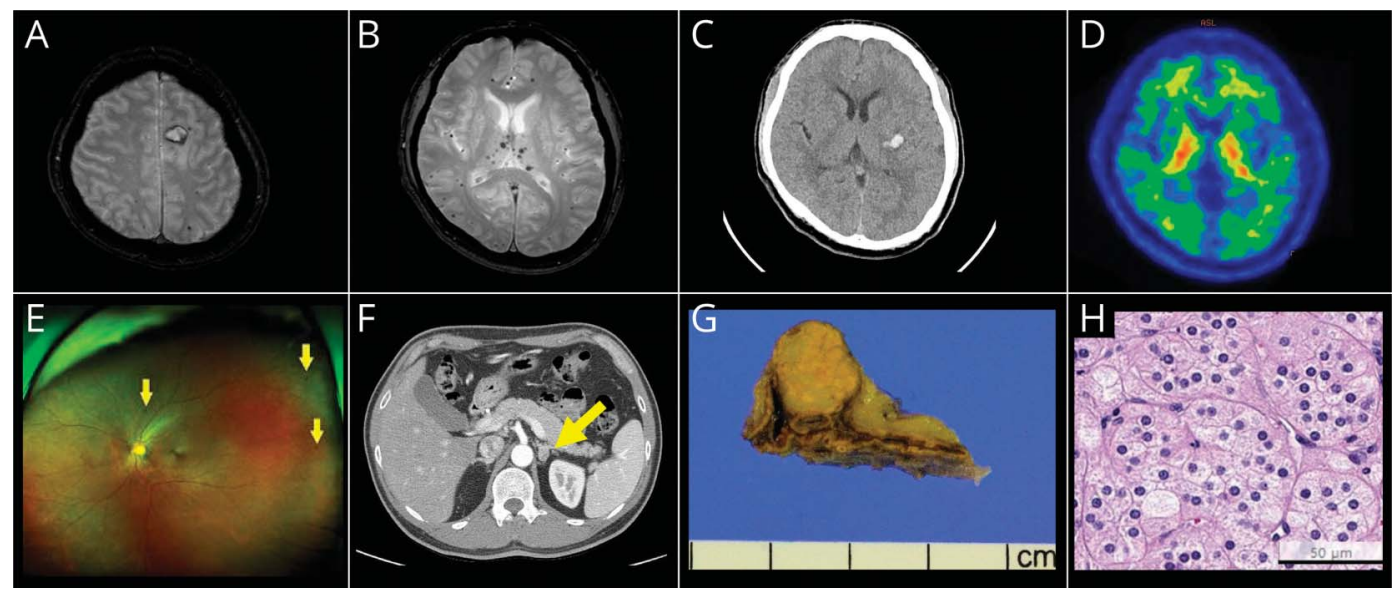

(A, B) Brain MRI. Gradient echo T2-weighted imaging shows an intracerebral hemorrhage (ICH) in the left superior frontal lobe and cerebral microbleeds (CMBs) in the Junction of white matter and gray matter, basal ganglia, and thalami. (C) An acute ICH in the left basal ganglia is seen in the brain CT. (D) ${ }^{18} \mathrm{~F}$ flutemetamol amyloid PET showed no amyloid deposition in brain. (E) Retinal dotty hemorrhages (arrows) are shown. (F) Adrenal CT shows a 1.7-cm mass in the left adrenal gland (arrow). (G) The adrenal mass is $1.3 \times 1.3 \times 1.3 \mathrm{~mL}$ and well-defined. (H) Adrenocortical adenoma is pathologically confirmed, based on microscopic findings: well-defined cell borders, polygonal pink cells, clear cells that have abundant, finely vacuolated cytoplasm, and nuclei that are central, round, and bland (hematoxylin \& eosin stating, at $400 \times$ magnification, bar $=50 \mu \mathrm{m}$ ).

During the patient's 10-day admission, his neurologic signs improved with only transcortical motor aphasia remained ( 1 on NIHSS), but his regimen was uptitrated to include a 4th antihypertensive medication. His blood test revealed low levels of serum potassium $(3.5 \mathrm{mmol} / \mathrm{L}$ on the first day of admission, 3.0 $\mathrm{mmol} / \mathrm{L}$ on the 4 th day of admission [normal range 3.5-5.1 $\mathrm{mmol} / \mathrm{L}]$ ); however, he did not show related symptoms or signs. NOTCH3 gene test did not detect any pathogenic/likely pathogenic variants. His $A P O E$ genotype was $\varepsilon 2 / \varepsilon 3$. ${ }^{18} \mathrm{~F}$ flutemetamol amyloid PET was conducted to exclude the possibility of combined CAA. The results revealed no evidence of brain amyloid deposition (figure, D). At follow-up 3 weeks after discharge, 24-hour ambulatory BP monitoring showed that his systolic BP was $110-130 \mathrm{~mm} \mathrm{Hg}$. Therefore, his antihypertensive medications were altered to include 3 again. Three months after the onset of the second ICH, he returned to work.

Six months after the patient's ICHs, a follow-up serum electrolyte test revealed low potassium levels $(2.7 \mathrm{mmol} / \mathrm{L})$. Therefore, he was recommended to stop taking the diuretic among his antihypertensive medications for 1 month. However, potassium levels were still low $(2.8 \mathrm{mmol} / \mathrm{L})$. He was supplemented with oral potassium chloride. After discontinuing the diuretic, his BP was 113/83 mm Hg. As a result, considering that he presented with numerous $\mathrm{CMBs}$ accompanied by 2 ICHs within an 18-day period, unexplained retinal hemorrhage (figure, E), and persistently low serum potassium, secondary hypertension was suspected. Subsequently, a hormonal test was conducted at $8 \mathrm{AM}$, which revealed the following results (normal range within parentheses): serum aldosterone $30.31 \mathrm{ng} / \mathrm{dL}$ (supine position, $4.1-20.8 \mathrm{ng} / \mathrm{dL}$ ) and plasma renin activity $\leq 0.20 \mathrm{ng} / \mathrm{mL} / \mathrm{h}$
$(0.5-1.9 \mathrm{ng} / \mathrm{mL} / \mathrm{h})$. The ratio of serum aldosterone $(\mathrm{ng} / \mathrm{dL})$ to plasma renin activity $(\mathrm{ng} / \mathrm{ml} / \mathrm{h})$ was over 20 , which indicated probable PA. A saline loading test was performed to confirm PA. After an IV injection of $2 \mathrm{~L}$ of normal saline for 4 hours, serum aldosterone level was $45.87 \mathrm{ng} / \mathrm{dL}$ and was not reduced to $<5 \mathrm{ng} / \mathrm{dL}$, which confirmed the PA. Adrenal CT (figure, F) showed a $1.7-\mathrm{cm}$ mass in the left adrenal gland. The adrenal mass, removed by laparoscopic left adrenalectomy, was a $1.3 \times 1.3 \times 1.3 \mathrm{~cm}^{3}$, well-defined adrenocortical adenoma (figure, $\mathrm{G}$ and $\mathrm{H}$ ). After surgical treatment, the patient's BP was under control with only 1 antihypertensive medication. He was diagnosed with secondary hypertension due to adrenocortical adenoma-related PA.

\section{Discussion}

This case study presents a patient with concomitant lobar and deep CMBs and ICHs caused by adrenocortical adenomarelated PA. Secondary hypertension was suspected because of the patient presenting with 2 consecutive ICHs over an 18day period, numerous CMBs, unexplained retinal hemorrhage, and persistently low serum potassium even after discontinuing his diuretic. The absence of amyloid deposition on his brain PET indicated that the CMBs could be explained by hypertensive small vessel disease due to PA rather than CAA.

Based on the modified Boston criteria, probable CAA is required to have multiple strictly lobar hemorrhages. Because CAA characteristically spares deep structures, any hemorrhagic lesions in basal ganglia, thalamus, or pons exclude the diagnosis of probable CAA. ${ }^{1}$ Deep CMBs correlate with MRI 
findings of hypertensive small vessel disease. ${ }^{1-3}$ Whereas our patient had multiple cortical CMBs and a recent lobar ICH without any other causes, he was younger than 55 and had $\mathrm{CMBs} / \mathrm{ICH}$ on deep territories. Therefore, his presentation did not satisfy well the criteria for probable CAA. However, mixed hemorrhagic lesions located in both lobar and deep territories, which was shown in our case, is another commonly encountered pattern and have posed substantial challenges to clinicians. A recent study demonstrated that mixed-location CMBs are caused by hypertensive small vessel disease rather than CAA. ${ }^{4}$ In addition, amyloid deposition was not revealed in the patient's brain PET. Therefore, his concomitant lobar and deep CMBs/ICHs were considered to be caused by hypertensive small vessel disease rather than CAA.

A more extensive workup of secondary causes of hypertension is warranted in patients with sudden onset of hypertension, aggravation of previously controlled hypertension, hypertension onset before age 30 , diastolic hypertension with onset after age 65 , malignant hypertension, drug-resistant or drug-induced hypertension, unprovoked hypokalemia, or excessive target organ damage for hypertension degree. ${ }^{5}$ Despite the prevalence of multiple CMBs increasing with age, $\geq 5 \mathrm{CMBs}$ were observed in only $1 \%$ of a population in their $60 \mathrm{~s}^{6}$ In this 47 -year-old patient with 7 years of hypertension, >200 mixed-location CMBs was suggestive of disproportionate target organ damage for degree of hypertension and together with his unprovoked hypokalemia warranted the investigation for secondary hypertension.

As revealed by current diagnostic methods, PA is the most common cause of secondary hypertension, with a prevalence rate of 5\%-15\% for patients with hypertension. ${ }^{7}$ It can cause cerebrovascular diseases, hypertension, electrolyte imbalance, and cardiovascular changes structurally and functionally. The increased stroke rate in PA may be related to the excessive aldosterone effects on blood vessels and direct damage from hypertension. Aldosterone itself produces oxidative stress, resulting in endothelial dysfunction and collagen remodeling, which causes vessel wall fibrosis. Taking into consideration that the BP of our patient was relatively well-controlled with medication and that hypertension itself is not an independent factor for frequency of CMBs, aldosterone may have contributed to the numerous CMBs in our patient. Whereas there have been a few case reports that described CMBs in $\mathrm{PA},{ }^{8,9}$ there were no reports investigating $\mathrm{CMBs}$ caused by secondary hypertension due to other causes such as pheochromocytoma. Future research is warranted to investigate the relationship between $\mathrm{CMBs}$ and aldosterone.

\section{Study Funding}

This research was supported by a Korea Health Technology R\&D Project grant through the Korea Health Industry Development Institute (KHIDI) funded by the Ministry of Health and Welfare, Republic of Korea (grant number HI18C0479), and a National Research Foundation of Korea (NRF) grant funded by the Korea government (Ministry of Science and ICT; grant number NRF-2019R1F1A1059660).

\section{Disclosure}

The authors report no disclosures relevant to the manuscript. Go to Neurology.org/N for full disclosures.

\section{Appendix Authors}

\begin{tabular}{lll}
\hline Name & Location & Contribution \\
\hline $\begin{array}{l}\text { Sun Min } \\
\text { Lee, MD, }\end{array}$ & $\begin{array}{l}\text { Department of Neurology, } \\
\text { Ajou University School of } \\
\text { PhD }\end{array}$ & $\begin{array}{l}\text { Cared for the patient, } \\
\text { interpreted the data, } \\
\text { Korea }\end{array}$ \\
\end{tabular}

\begin{tabular}{lll}
\hline $\begin{array}{l}\text { Yong Jun } \\
\text { Choi, MD, } \\
\text { PhD }\end{array}$ & $\begin{array}{l}\text { Department of Endocrinology, } \\
\text { Ajou University School of } \\
\text { Medicine, Suwon, Republic of } \\
\text { Korea }\end{array}$ & $\begin{array}{l}\text { Cared for the patient, } \\
\text { interpreted the data, } \\
\text { approved final version of } \\
\text { the paper }\end{array}$ \\
\hline $\begin{array}{l}\text { Kihwang } \\
\text { Lee, MD, } \\
\text { PhD }\end{array}$ & $\begin{array}{l}\text { Department of } \\
\text { Ophthalmology, Ajou } \\
\text { University School of Medicine, } \\
\text { Suwon, Republic of Korea }\end{array}$ & $\begin{array}{l}\text { Cared for the patient, } \\
\text { interpreted the data, } \\
\text { approved final version of } \\
\text { the paper }\end{array}$ \\
\hline
\end{tabular}

\begin{tabular}{lll}
\hline Hyeung & Department of Thyroid & $\begin{array}{l}\text { Cared for the patient, } \\
\text { Kyoo Kim, } \\
\text { MD }\end{array}$ \\
$\begin{array}{l}\text { Endocrinology Surgery, Ajou } \\
\text { University School of Medicine, } \\
\text { Suwon, Republic of Korea }\end{array}$ & $\begin{array}{l}\text { approved final version of } \\
\text { the paper }\end{array}$ \\
\hline
\end{tabular}

\begin{tabular}{lll}
\hline Jin-Sun & Department of Cardiology, & $\begin{array}{l}\text { Cared for the patient, } \\
\text { interpreted the data, } \\
\text { Park, MD, }\end{array}$ \\
PhD & $\begin{array}{l}\text { Ajou University School of } \\
\text { Medicine, Suwon, Republic of } \\
\text { Korea }\end{array}$ & $\begin{array}{l}\text { approd final version of } \\
\text { the paper }\end{array}$
\end{tabular}

Yong Department of Neurosurgery, Cared for the patient,

$\begin{array}{lll}\text { Yong } & \text { Department of Neurosurgery, } & \begin{array}{l}\text { Cared for the patient, } \\ \text { Cheol }\end{array} \\ \text { ajou University School of }\end{array}$

Lim, MD Medicine, Suwon, Republic of the paper Korea

\begin{tabular}{lll}
\hline $\begin{array}{l}\text { Jang-Hee } \\
\text { Kim, MD }\end{array}$ & $\begin{array}{l}\text { Department of Pathology, } \\
\text { Ajou University School of } \\
\text { Medicine, Suwon, Republic of } \\
\text { Korea }\end{array}$ & $\begin{array}{l}\text { Interpreted the data, } \\
\text { approved final version of } \\
\text { the paper }\end{array}$ \\
\hline $\begin{array}{l}\text { So Young } \\
\text { Moon, } \\
\text { MD, PhD }\end{array}$ & $\begin{array}{l}\text { Department of Neurology, } \\
\text { Ajou University School of } \\
\text { Medicine, Suwon, Republic of } \\
\text { Korea }\end{array}$ & $\begin{array}{l}\text { Cared for the patient } \\
\text { presented, interpreted the } \\
\text { data, revised the draft } \\
\text { critically for important } \\
\text { intellectual content, } \\
\text { approved final version of } \\
\text { the paper }\end{array}$ \\
\end{tabular}

\section{References}

1. Greenberg SM, Charidimou AJS. Diagnosis of cerebral amyloid angiopathy: evolution of the Boston criteria. Stroke 2018;49:491-497.

2. Park JH, Seo SW, Kim C, et al. Pathogenesis of cerebral microbleeds: in vivo imaging of amyloid and subcortical ischemic small vessel disease in 226 individuals with cognitive impairment. Ann Neurol 2013;73:584-593.

3. Johnson KA, Gregas M, Becker JA, et al. Imaging of amyloid burden and distribution in cerebral amyloid angiopathy. Ann Neurol 2007;62:229-234.

4. Tsai HH, Pasi M, Tsai LK, et al. Microangiopathy underlying mixed-location intracerebral hemorrhages/microbleeds: a PiB-PET study. Neurology 2019;92:e774-e781.

5. Whelton PK, Carey RM, Aronow WS, et al. 2017 ACC/AHA/AAPA/ABC/ACPM/ AGS/APhA/ASH/ASPC/NMA/PCNA guideline for the prevention, detection, evaluation, and management of high blood pressure in adults: a report of the American College of Cardiology/American Heart Association task force on clinical practice guidelines. Circulation 2018;138:e484-e594.

6. Graff-Radford J, Botha H, Rabinstein AA, et al. Cerebral microbleeds: prevalence and relationship to amyloid burden. Neurology 2019;92:e253-e262.

7. Chen ZW, Hung CS, Wu VC, Lin YH, Ts group. Primary aldosteronism and cerebrovascular diseases. Endocrinol Metab 2018;33:429-434.

8. Miyata K, Imaizumi T, Horita Y, et al. Multiple intracerebral microhemorrhages associated with primary aldosteronism: a case report. No Shinkei Geka 2003;31: 1223-1227.

9. Hsu CC, Singh D, Watkins TW, Kwan GNC, Hapugoda S. High resolution magnetic resonance imaging for exposing facial nerve zonal vulnerability to microbleeds: a rare cause of facial palsy. Neuroradiol J 2017;30:385-388. 


\section{Neurology}

\section{Pearls \& Oy-sters: Cerebral Microbleeds Caused by Adrenocortical Adenoma-Related Primary Aldosteronism}

Sun Min Lee, Yong Jun Choi, Kihwang Lee, et al.

Neurology 2021;96;960-962 Published Online before print April 7, 2021

DOI 10.1212/WNL.0000000000011934

\section{This information is current as of April 7, 2021}

\section{Updated Information \&} Services

References

Subspecialty Collections

Permissions \& Licensing

Reprints including high resolution figures, can be found at: http://n.neurology.org/content/96/20/960.full

This article cites 9 articles, 3 of which you can access for free at: http://n.neurology.org/content/96/20/960.full\#ref-list-1

This article, along with others on similar topics, appears in the following collection(s):

All Cerebrovascular disease/Stroke

http://n.neurology.org/cgi/collection/all_cerebrovascular_disease_strok e

All Clinical Neurology

http://n.neurology.org/cgi/collection/all_clinical_neurology

Endocrine

http://n.neurology.org/cgi/collection/endocrine

MRI

http://n.neurology.org/cgi/collection/mri

Stuttering

http://n.neurology.org/cgi/collection/stuttering

Information about reproducing this article in parts (figures,tables) or in its entirety can be found online at:

http://www.neurology.org/about/about_the_journal\#permissions

Information about ordering reprints can be found online:

http://n.neurology.org/subscribers/advertise

Neurology ${ }^{\circledR}$ is the official journal of the American Academy of Neurology. Published continuously since 1951, it is now a weekly with 48 issues per year. Copyright () 2021 American Academy of Neurology. All rights reserved. Print ISSN: 0028-3878. Online ISSN: 1526-632X.

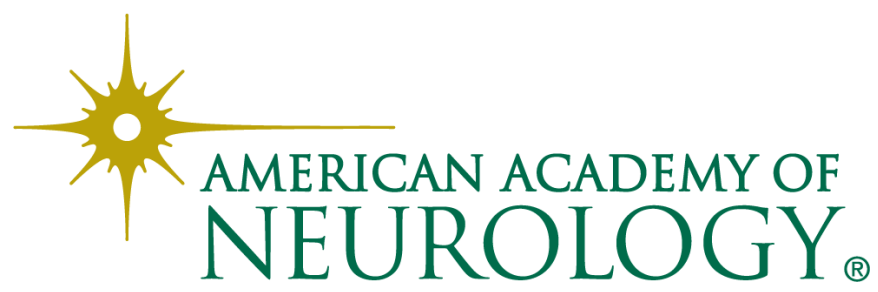

